\title{
Kajian Pengaruh Residu Kompos Biochar dan Aplikasi Teh Kompos terhadap Pembentukkan Bawang Putih (Allium sativum L.) Siung Tunggal Menggunakan Bibit Asal Bagian Luar Siung Majemuk pada Penanaman Tahun kedua
}

Eduardus Yosef Neonbeni ${ }^{\mathrm{a}}$ dan Adriana Hoar ${ }^{\mathrm{b}}$

${ }^{a}$ Fakultas Pertanian, Universitas Timor, Kefamenanu, TTU - NTT, Indonesia, email: ambeni02@ gmail.com

${ }^{b}$ Fakultas Pertanian, Universitas Timor, Kefamenanu, TTU - NTT, Indonesia, email: adrianahoar11996@ gmail.com

\section{Article Info}

Article history:

Received 22 Juni 2020

Received in revised form 19 Juli 2020

Accepted 27 Juli 2020

DOI:

https://doi.org/10.32938/sc.v5i03.1055

\section{Keywords:}

Bawang putih

Siung tunggal

Residu

Kompos biochar,

Teh kompos

\section{Abstrak}

Penelitian bertujuan untuk mengetahui pengaruh residu kompos biochar pada penanaman tahun kedua dan aplikasi teh kompos yang tepat terhadap pembentukan bawang putih (Allium sativum L. ) siung tunggal menggunakan bibit asal bagian luar siung majemuk. Penelitian dilaksanakan bulan Juni sampai dengan bulan September 2019, di kebun percobaan Fakultas Pertanian, Universitas Timor, Kelurahan Sasi Kecamatan Kota Kefamenanu, Kabupaten Timor Tengah Utara. Menggunakan Rancangan Acak Kelompok (RAK) faktorial 3x3. Faktor pertama adalah residu kompos biochar yang diaplikasikan satu tahun sebelumnya, yang terdiri dari 3 aras yaitu tanpa kompos biochar, kompos ditambah biochar $10 \%$, kompos ditambah biochar $20 \%$. Faktor kedua adalah aplikasi jenis teh kompo yang terdiri dari 3 aras yaitu, tanpa teh kompos, teh kompos murni, kompos ditambahakan biochar, yang diulang sebanyak 3 kali ditambah dengan kontrol sehingga terdapat 30 unit petak percobaan. Hasil penelitian membuktikan bahwa terjadi interaksi antara kombinasi perlakuan residu kompos biochar $10 \%$ dan perlakuan aplikasi teh kompos murni terhadap kadar lengas tanah 45 HST, dan jumlah umbi per petak. Walaupun tidak terjadi interaksi antar perlakuan residu kompos murni dengan jenis teh kompos murni menghasilkan bobot umbi siung tunggal per petak terberat 0,93 t/ha. Pengaruh utama perlakuan residu kompos biochar $10 \%$ lebih meningkatkan hasil bobot umbi total, bobot umbi siung tunggal, dan bobot umbi siung majemuk walaupun tidak berbeda nyata. Pengaruh utama perlakuan aplikasi teh kompos biochar meningkatkan hasil bobot umbi total, bobot umbi siung tunggal, sedangkan bobot umbi majemuk hasilnya lebih tinggi apabila menerapkan teh kompos murni.

\section{Pendahuluan}

Bawang putih (Allium sativum L.) merupakan salah satu komoditas pertanian yang dibutuhkan oleh banyak orang karena memiliki berbagai manfaat sebagai pewangi dan penyedap makanan. Kandungan bawang putih secara klinis sudah dibuktikan bahwa manfaatnya termasuk dalam pengobatan untuk penyakit diabetes, hipertensi, demam dan juga sebagai penghambat tumbuhnya tumor. Banyak juga terdapat dalam publikasi ilmiah yang menunjukkan bahwa bawang putih memiliki potensi farmakologis sebagai agen anti bakteri, anti hipertensi dan anti trombotik (Prasonto et al., 2017). Umbi bawang putih terdiri dari zat organis yaitu: protein $(4,50 \mathrm{~g})$, lemak $(0,20 \mathrm{~g})$ dan hidrat arang $(23,10 \mathrm{~g})$. Selain itu terdapat kalsium $(42 \mathrm{mg})$, fosfor $(134 \mathrm{mg})$, besi (1 mg), vitamin C (15 mg), vitamin B1 (0,22 mg), air (71 g) dan kalori (95 kal) (Direktorat Gizi Departemen Kesehatan RI, 1997).

Indonesia merupakan negara penghasil bawang, baik itu bawang merah maupun bawang putih. Namun dilihat dari nilai impor yang ditunjukan dalam beberapa tahun belakangan ini terhadap komoditas bawang merah dan bawang putih cukup tinggi. Data produksi bawang putih dari tahun 2009 hingga 2013 berturut-turut adalah: 17. 313, 12.339, 15. 419, 12.295 dan 14. 749 ton. Impor bawang putih pada bulan Januari 2013 mencapai 23. 000 ton. Produksi bawang putih dalam negeri hanya bisa memenuhi $5 \%$ dari kebutuhan nasional, sedangkan $95 \%$ kekurangannya masih dipenuhi oleh impor. Berbeda halnya dengan keadaan komoditas bawang merah di Indonesia (BPS RI, 2014). Data produksi bawang putih di Kabupaten Timor Tengah Utara (TTU) dari tahun 2007 hingga 2010 mengalami fluktuasi. Pada tahun 2007 produksi bawang putih mencapai 80 ton, namun pada tahun 2010 mengalami penurunan hingga 12 ton (BPS Kab. TTU, 2011). Bawang putih di Kabupaten Timor Tengah Utara mempunyai nilai ekonomis yang sangat tinggi, sehingga dapat dikelompokan menjadi tanaman unggulan yang menghasilkan nilai ekonomis dan pendapatan bagi masyarakat. Menurut hasil observasi di Pasar Tradisional Kota Kefamenanu (TTU) pada bulan Februari 2020 menunjukkan bahwa bawang putih siung tunggal memiliki nilai ekonomis yang tinggi yakni Rp 100.000 perkilogram dibandingkan dengan bawang putih siung majemuk dengan harga $\mathrm{Rp} 85.000$ perkilogram, dikarenakan bawang putih siung tunggal mengandung senyawa ogganosulfur bernama diallyl trisulfide senyawa tersebut mampu membantu kinerja hati untuk mengeluarkan racun pada tubuh, selain itu bawang putih siung tunggal juga bisa dikomsumsi dengan keadaan mentah. Hal ini mendorong banyak masyarakat yang ingin membudidayakan tanaman bawang siung tunggal.

Beberapa penyebab rendahnya produksi bawang putih diantaranya adalah teknik budidaya yang kurang tepat, kualitas bibit yang rendah, serangan hama dan penyakit, selain itu kondisi lahan pertanian di wilayah TTU pada umumnya adalah daerah lahan kering yang miskin akan unsur hara dan daya tahan terhadap air sangat minim. Untuk meningkatkan produksi bawang putih maka perlu adanya teknologi yang dapat memperbaiki kesuburan tanah, teknologi yang dapat diterapkan adalah dengan menerapkan kompos biochar dan aplikasi teh kompos. Permasalahannya adalah seberapa lama kompos biochar dapat bertahan dan menunjang peningkatan hasil tanaman. Selain itu apakah residu kompos biochar dapat kembali dimanfaatkan. Selanjutnya aplikasi teh kompos diharapkan dapat mengatasi penurunan ketersediaan unsur hara akibat dekomposisi dan pelindian (leaching) setelah satu tahun aplikasi kompos biochar. Residu merupakan sisa-sisa dari bahan organik yang tertinggal di dalam tanah. Residu akan memberikan dampak yang baik bagi pertumbuhan tanaman. Pemanfaatan residu pupuk organik akan berdampak baik pada kesuburan tanah selama beberapa tahun (Tas'au, 2018). Pupuk kompos merupakan salah satu jenis pupuk organik yang terjadi karena proses penghancuran bahan-bahan organik hasil kerja sama faktor lingkungan dan mikroorganisme (Mulyono, 2014).

Kompos memiliki unsur hara lengkap baik makro maupun mikro dan sangat dibutuhkan tanaman untuk pertumbuhan dan produksi. Kompos dapat memperbaiki sifat fisik tanah seperti struktur tanah, tekstur tanah, memperbaiki tata air dan udara tanah, memperbaiki suhu tanah menjadi lebih stabil, mempertinggi daya ikat tanah terhadap zat hara sehingga tidak mudah larut oleh air. Selain itu, kompos dapat memperbaiki sifat kimiawi tanah karena daya absorbs dan daya tukar kation yang besar. Kompos juga dapat memperbaiki sifat biologis tanah yaitu memperbaiki kehidupan mikroorganisme di dalam tanah sangat baik untuk konservasi tanah pada lahan kering (Retno dan Darmanti, 2009). Hasil penelitian Fretis (2018) sebelumnya menunjukkan bahwa kompos yang ditambah biochar $10 \%$ dan teh kompos ditambah biochar memberikan hasil yang tertinggi pada bobot kering siung tunggal per umbi $(0,70 \mathrm{~g} / \mathrm{umbi})$ dan indeks panen $(76,69 \mathrm{~g})$, dibandingkan yang diberi perlakuan kompos + biochar $20 \%$. Oleh karena itu perlu melakukan penelitian tentang kajian pengaruh residu kompos biochar dan aplikasi teh kompos terhadap pembentukan bawang putih (Allium sativum L.) siung tunggal menggunakan bibit asal bagian luar siung majemuk pada penanaman tahun kedua.

Menurut Jamilah et al.,(2008) menyatakan bahwa pada tanaman bawang merah residu kompos $C$. odorata dengan takaran $150 \mathrm{~kg}$ mampu meningkatkan tinggi tanaman paling tinggi $(49,26 \mathrm{~g})$, berat akar tanaman (1,66 g), jurnlah umbi bawang tertinggi $(11,33 \mathrm{~g})$, berat umbi segar meningkat $(156,13 \mathrm{~g})$. Hal ini membuktikan bahwa residu kompos $C$. odorata dan guano yang dikomposkan telah mampu meningkatkan kesuburan pada beberapa tahun dan menghasilkan tanaman bawang jauh lebih tinggi dibandingkan dengan apa yang telah dilakukan oleh jenis residu kompos lainnya. Hasil penelitian Samira, (2012) menunjukkan bahwa residu biochar 10 t/ha berpengaruh nyata terhadap N-Total tanah, kapasitas tukar kation (KTK), jumlah gabah total dan hasil per hektar, tinggi tanaman, jumlah anakan, jumlah malai/rumpun, persentase gabah hampa/malai, persentase gabah berisi/malai dan hasil per hektar. Biochar merupakan bahan pembenah tanah yang mampu bertahan dalam jangka waktu yang cukup lama. Menurut Fretis (2018) pada lahan penelitian yang sama pada musim tanam pertama menyatakan bahwa pada pemberian kompos + biochar $10 \%$ dan teh kompos biochar memberikan hasil yang tertinggi pada bobot kering siung tunggal per umbi $(0,70 \mathrm{~g} / \mathrm{umbi})$ dan indeks panen tertinggi $(76,69$ g). Berdasarkan uraian diatas maka penelitian bertujuan untuk mengetahui pengaruh residu kompos biochar pada penanaman tahun kedua dan aplikasi teh kompos yang tepat terhadap pembentukan bawang putih (Allium sativum L.) siung tunggal menggunakan bibit asal bagian luar siung majemuk.

\section{Metode}

Penelitian ini dilaksanakan pada bulan Juni sampai September 2019, bertempat dikebun percobaan Fakultas Pertanian, Universitas Timor, Kelurahan Sasi, Kecamatan Kota Kefamenanu, Kabupaten Timor Tengah Utara. Percobaan lapangan mengguanakan Rancangan Acak Kelompok (RAK) dengan 2 faktorial. Faktor pertama adalah biochar yang sudah diaplikasikan satu tahun lalu (S), yang terdiri dari 3 aras yaitu tanpa biochar $\left(\mathrm{S}_{0}\right)$, biochar $10 \%\left(\mathrm{~S}_{1}\right)$, biochar $20 \%\left(\mathrm{~S}_{2}\right)$. Faktor kedua adalah teh kompos $(\mathrm{K})$ yang terdiri dari 3 aras 
yaitu, tanpa teh kompos $\left(\mathrm{K}_{0}\right)$, teh kompos murni $\left(\mathrm{K}_{1}\right)$, kompos diperkaya biochar $\left(\mathrm{K}_{2}\right)$. Dengan demikian diperoleh 9 kombinasi perlakuan adalah $\mathrm{S}_{0} \mathrm{~K}_{0}$, $\mathrm{S}_{0} \mathrm{~K}_{1}, \mathrm{~S}_{0} \mathrm{~K}_{2}, \mathrm{~S}_{1} \mathrm{~K}_{0}, \mathrm{~S}_{1} \mathrm{~K}_{1}, \mathrm{~S}_{1} \mathrm{~K}_{2}, \mathrm{~S}_{2} \mathrm{~K}_{0}, \mathrm{~S}_{2} \mathrm{~K}_{1}, \mathrm{~S}_{2} \mathrm{~K}_{2}$, yang diulang 3 kali, sehingga diperoleh 27 unit percobaan dan ditambah dengan kontrol 3, sehingga diperoleh 30 petak percobaan. Parameter suhu udara $\left({ }^{\circ} \mathrm{C}\right)$ dan kelembaban $(\%), \mathrm{pH}$ tanah dan DHL tanah, kadar lengas tanah, berat volume tanah, suhu tanah, jumlah daun (helai), luas daun. jumlah umbi per petak (siung tunggal dan siung majemuk), presentase jumlah pembentukan umbi siung tunggal per petak, Berat panen umbi (siung tunggal dan siung majemuk) (t/ha), berat panen akar (siung tunggal dan siung majemuk) (g), berat kering umbi per tanaman (siung tunggal dan siung majemuk) (g), Berat kering akar (siung tunggal dan siung majemuk) (g), berat kering umbi per tanaman (siung tunggal dan siung majemuk) (t/ha), presentase bobot siung tunggal per petak (\%), Berat kering berangkasan (siung tunggal dan siung majemuk), indeks panen (\%).

Data hasil pengamatan kemudian dianalisis dengan menggunakan sidik ragam (anova) kelompok (RAK) 2 faktorial. Rata-rata perlakuan selanjutnya diuji lanjut dengan menggunakan Duncan Multiple Range Test (DMRT) dengan tingkat signifikan $5 \%$ sesuai petunjuk Gomez dan Gomez (2010). Analisis data menggunakan program SAS 9. 1.

\section{Hasil dan Pembahasan}

\subsection{Hasil}

\section{Rerata Suhu dan Kelembaban Udara}

Suhu dan kelembaban merupakan salah satu aspek yang penting dalam menentukan kondisi cuaca lingkungan. Suhu merupakan panas atau dinginnya suatu lingkungan yang diukur menggunakan termometer sedangkan kelembaban merupakan banyaknya uap air yang terkandung dalam udara atau atmosfer. Suhu dan kelembapan udara tidak tetap selama waktu pengamatan. Pada saat dingin suhunya menurun dan kelembapannya tinggi sedangkan pada saat panas suhunya tinggi dan kelembapannya menurun. Perubahan suhu dan kelembaban lingkungan dapat dilihat pada Gambar 1 dan Gambar 2.

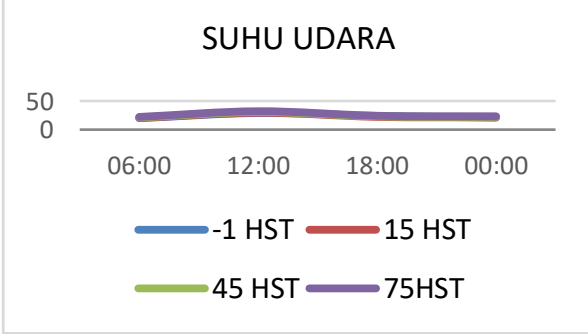

Gambar 1. Perubahan Suhu Lingkungan

\section{KELEMBABAN UDARA}

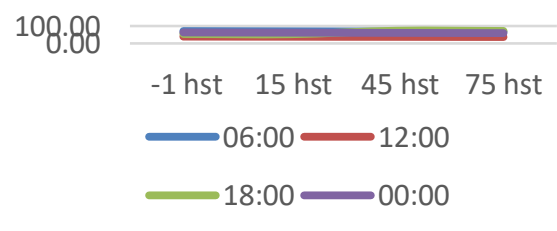

Gambar 2. Perubahan Kelembaban Lingkungan

\section{Suhu Tanah}

Hasil sidik ragam (anova) menunjukkan bahwa tidak terjadi interaksi antara perlakuan residu kompos biochar dan aplikasi teh kompos pada pengamatan suhu tanah. Perlakuan residu kompos biochar $20 \%$ menghasilkan suhu tanah terendah $\left(27,98^{\circ} \mathrm{C}\right)$ namun tidak berbeda nyata dengan aras perlakuan lainnya. Sedangkan petak yang diberikan perlakuan teh kompos murni menghasilkan suhu tanah terendah $\left(27,83{ }^{\circ} \mathrm{C}\right)$ namun tidak berbeda nyata dengan aras perlakuan lainnya pada waktu pengamatan -1 HST. Pada waktu pengamatan 15 HST, Pengaruh utama perlakuan residu kompos biochar $10 \%$ mampu menurunkan suhu tanah yaitu $\left(28,12{ }^{\circ} \mathrm{C}\right)$ namun tidak ada beda nyata antara aras perlakuan. Petak yang diberi perlakuan aplikasi teh kompos + biochar memiliki suhu tanah paling rendah $\left(28,52^{\circ} \mathrm{C}\right)$ namun tidak berbeda nyata antara perlakuan. Waktu pengamatan 45 HST, menunjukkan bahwa Pengaruh utama perlakuan residu kompos biochar $20 \%$ menghasilkan suhu tanah paling rendah $\left(29,26{ }^{\circ} \mathrm{C}\right)$ namun tidak ada beda nyata antara aras perlakuan (Tabel 1). Petak yang diberi perlakuan aplikasi teh kompos + biochar menghasilkan suhu tanah paling rendah $\left(28,52{ }^{\circ} \mathrm{C}\right)$ namun tidak ada beda nyata antara perlakuan. Sedangkan pada waktu pengamatan $75 \mathrm{HST}$, pengaruh utama perlakuan residu kompos biochar $20 \%$ menghasilkan suhu tanah paling rendah $\left(29,37^{\circ} \mathrm{C}\right)$ namun tidak berbeda nyata antara aras perlakaun. Sedangkan petak yang diberi perlakuan aplikasi teh kompos murni memiliki nilai suhu tanah paling rendah $\left(29,27^{\circ} \mathrm{C}\right)$. Walaupun tidak terjadi interaksi antara kombinasi perlakuan, namun kombinasi perlakuan residu kompos biochar $20 \%$ dan aplikasi teh kompos murni menghasilkan suhu tanah paling rendah, tertinggi dihasilkan oleh kontrol.

\begin{tabular}{|c|c|c|c|c|c|}
\hline \multirow{2}{*}{$\begin{array}{l}\text { Waktu } \\
\text { Pengamatan } \\
\text { (HST) }\end{array}$} & \multirow{2}{*}{$\begin{array}{l}\text { Residu } \\
\text { Kompos } \\
\text { Biochar }\end{array}$} & \multicolumn{3}{|c|}{ Jenis Teh Kompos } & \multirow[b]{2}{*}{ Rerata } \\
\hline & & Tanpa & Murni & Teh + Biochar & \\
\hline \multirow{5}{*}{0} & Murni & 28,27 & 28,63 & 28,06 & $28,32 \mathrm{a}$ \\
\hline & Biochar $10 \%$ & 28,03 & 27,67 & 28,67 & $28,12 \mathrm{a}$ \\
\hline & Biochar $20 \%$ & 28,17 & 27,19 & 28,57 & $27,98 \mathrm{a}$ \\
\hline & Rerata & $28,16 \mathrm{a}$ & $27,83 \mathrm{a}$ & $28,43 \mathrm{a}$ & $(-)$ \\
\hline & Kontrol & & 29,56 & & \\
\hline \multirow{5}{*}{15} & Murni & 29,22 & 29,19 & 28,66 & $29,02 \mathrm{a}$ \\
\hline & Biochar $10 \%$ & 28,81 & 28,34 & 27,40 & $28,19 \mathrm{a}$ \\
\hline & Biochar $20 \%$ & 29,34 & 28,24 & 29,50 & $29,03 \mathrm{a}$ \\
\hline & Rerata & $29,13 \mathrm{a}$ & $28,59 \mathrm{a}$ & $28,52 \mathrm{a}$ & $(-)$ \\
\hline & Kontrol & & 30,02 & & \\
\hline \multirow{5}{*}{45} & (Murni) & 30,21 & 30,34 & 29,54 & $30,03 a$ \\
\hline & Biochar $10 \%$ & 29,91 & 29,29 & 29,34 & $29,51 \mathrm{a}$ \\
\hline & Biochar $20 \%$ & 28,69 & 29,50 & 29,58 & $29,26 \mathrm{a}$ \\
\hline & Rerata & $29,60 \mathrm{a}$ & $29,71 \mathrm{a}$ & $29,49 \mathrm{a}$ & $(-)$ \\
\hline & Kontrol & & 30,37 & & \\
\hline \multirow{5}{*}{75} & Murni & 30,46 & 30,01 & 30,03 & $30,17 \mathrm{a}$ \\
\hline & Biochar $10 \%$ & 30,34 & 29,53 & 29,91 & $29,93 a$ \\
\hline & Biochar $20 \%$ & 29,77 & 28,26 & 30,10 & $29,37 \mathrm{a}$ \\
\hline & Rerata & $30,19 \mathrm{a}$ & $29,27 \mathrm{a}$ & $30,01 \mathrm{a}$ & $(-)$ \\
\hline & Kontrol & & 30,69 & & \\
\hline
\end{tabular}

Keterangan: Angka pada baris dan kolom yang diikuti huruf sama menunjukkan tidak berbeda pada tingkat nyata (a) 5\% menurut uji DMRT. (-) tidak terjadi interaksi antar faktor.

\section{Kadar Lengas Tanah}

Hasil sidik ragam (anova) menujukkan tidak terjadi interaksi antara perlakuan residu kompos biochar dan aplikasi teh kompos pada pengamatan kadar lengas tanah. Perlakuan residu kompos biochar $10 \%$ menghasilkan kadar lengas tanah tertinggi $(20,40 \%)$ dan berbeda nyata dengan aras perlakuan lainnya. Sedangkan petak yang diberikan perlakuan tanpa teh kompos menghasilkan lengas tanah tanah tertinggi $(19,75 \%)$ namun tidak berbeda nyata dengan aras perlakuan lainnya pada waktu pengamatan -1 HST. Pada waktu pengamatan 15 HST, Pengaruh utama perlakuan residu kompos biochar $20 \%$ memiliki nilai lengas tanah tinggi yaitu $(28,88 \%)$ dan berbeda nyata antara aras perlakuan. Petak yang diberi perlakuan aplikasi teh kompos murni memberikan nilai lengas tanah tertinggi $(29,28 \%)$ dan berbeda nyata dengan perlakuan lainnya. Waktu pengamatan 45 HST, menunjukkan bahwa terjadi interaksi kombinasi perlakuan. Kombinasi perlakuan residu kompos biochar 10 $\%$ dan aplikasi teh kompos murni menghasilkan legas tanah tertinggi $(27,80 \%)$ dan berbeda sangat nyata antara kombinasi perlakuan terendah dihasilkan oleh kontrol atau tanpa perlakuan $(20,76 \%)$. Sedangkan pada waktu pengamatan 75 HST tidak terjadi interaksi antara kombinasi perlakuan. Pengaruh utama tanpa perlakuan menghasilkan lengas tanah tertinggi $(20,84 \%)$ namun tidak berbeda nyata antara aras perlakuan. Sedangkan petak yang diberi perlakuan aplikasi teh kompos + biochar memiliki nilai lengas tanah tertinggi $(20,71 \%)$ dan berbeda nyata antara perlakuan. Rata-rata kombinasi perlakuan residu kompos biochar $10 \%$ dan aplikasi teh kompos murni menghasilkan kadar lengas tanah tertinggi pada setiap waktu dan terendah dihasilkan oleh kontrol (Tabel 2)

\section{Berat Volume Tanah}

Hasil sidik ragam (anova) menujukkan tidak terjadi interaksi antara perlakuan residu kompos biochar dan aplikasi teh kompos pada pengamatan berat volume tanah. Perlakuan residu kompos biochar $20 \%$ menghasilkan berat volume tanah terendah $\left(1,49 \mathrm{~g} / \mathrm{cm}^{3}\right)$ dan berbeda nyata antara aras perlakuan lainnya. Sedangkan petak yang diberikan perlakuan teh kompos murni menghasilkan berat volume tanah terendah $\left(1,57 \mathrm{~g} / \mathrm{cm}^{3}\right)$ namun tidak berbeda nyata dengan aras perlakuan lainnya pada waktu pengamatan -1 HST Pada waktu pengamatan 15 HST, Pengaruh utama tanpa perlakuan residu kompos biochar mampu menurunkan berat volume tanah yaitu $\left(1,57 \mathrm{~g} / \mathrm{cm}^{3}\right)$ namun tidak ada beda nyata antara aras perlakuan. Petak yang diberi perlakuan aplikasi teh kompos + biochar memiliki tekstur tanah paling ringan $(1,59$ $\mathrm{g} / \mathrm{cm}^{3}$ ) namun tidak berbeda nyata antara perlakuan. Waktu pengamatan 45 HST, menunjukkan bahwa pengaruh utama perlakuan tanpa residu kompos biochar menghasilkan berat volume tanah paling rendah $\left(1,58 \mathrm{~g} / \mathrm{cm}^{3}\right)$ namun tidak ada beda nyata antara aras perlakuan. Petak yang diberi perlakuan aplikasi teh kompos murni menghasilkan berat volume tanah paling ringan $\left(1,57 \mathrm{~g} / \mathrm{cm}^{3}\right)$ namun tidak ada beda nyata antara perlakuan. Pada waktu pengamatan 75 HST, pengaruh utama perlakuan tanpa residu kompos biochar menghasilkan berat volume tanah paling rendah $\left(1,53 \mathrm{~g} / \mathrm{cm}^{3}\right)$ namun tidak berbeda nyata antara aras perlakaun. Sedangkan petak yang diberi perlakuan aplikasi teh kompos murni memiliki nilai berat volume tanah paling rendah $\left(1,53 \mathrm{~g} / \mathrm{cm}^{3}\right)$. Walaupun tidak terjadi interaksi antara kombinasi perlakuan, namun kombinasi perlakuan residu kompos biochar $20 \%$ dan aplikasi teh kompos murni menghasilkan berat volume tanah paling rendah, tertinggi dihasilkan oleh kontrol (Tabel 3) 
Tabel 2. Kadar Lenggas Tanah (\%)

\begin{tabular}{|c|c|c|c|c|c|}
\hline \multirow{2}{*}{$\begin{array}{c}\text { Waktu } \\
\text { Pengamatan } \\
\text { (HST) }\end{array}$} & \multirow{2}{*}{$\begin{array}{c}\text { Residu Kompos } \\
\text { Biochar }\end{array}$} & \multicolumn{3}{|c|}{ Jenis Teh Kompos } & \multirow[b]{2}{*}{ Rerata } \\
\hline & & Tanpa & Murni & Teh + Biochar & \\
\hline \multirow{5}{*}{0} & Murni & 18,05 & 19,53 & 17,12 & $18,23 \mathrm{~b}$ \\
\hline & Biochar10\% & 20,94 & 18,81 & 21,45 & $20,40 \mathrm{a}$ \\
\hline & Biochar $20 \%$ & 20,24 & 19,99 & 20,45 & $20,23 \mathrm{a}$ \\
\hline & Rerata & $19,75 \mathrm{a}$ & $19,44 \mathrm{a}$ & $19,67 \mathrm{a}$ & $(-)$ \\
\hline & Kontrol & \multicolumn{3}{|c|}{18,08} & \\
\hline \multirow{5}{*}{15} & Murni & 20,76 & 27,98 & 27,26 & $25,33 b$ \\
\hline & Biochar $10 \%$ & 26,41 & 29,12 & 29,06 & $28,20 \mathrm{a}$ \\
\hline & Biochar $20 \%$ & 26,90 & 30,73 & 29,00 & $28,88 \mathrm{a}$ \\
\hline & Rerata & $24,69 \mathrm{~b}$ & $29,28 \mathrm{a}$ & $28,44 a$ & $(-)$ \\
\hline & Kontrol & \multicolumn{3}{|c|}{22,85} & \\
\hline \multirow{5}{*}{45} & Murni & $21,26 \mathrm{f}$ & $25,83 \mathrm{bcd}$ & $26,83 a b c$ & $24,64 b$ \\
\hline & Biochar $10 \%$ & $24,11 \mathrm{e}$ & $27,80 \mathrm{a}$ & $27,02 \mathrm{ab}$ & $26,31 \mathrm{a}$ \\
\hline & Biochar 20\% & $24,84 \mathrm{ed}$ & $26,73 a b c$ & 25,34 cde & $25,64 \mathrm{a}$ \\
\hline & Rerata & $23,40 \mathrm{~b}$ & $26,79 a$ & $26,40 \mathrm{a}$ & $(+)$ \\
\hline & Kontrol & \multicolumn{3}{|c|}{20,76} & \\
\hline \multirow{5}{*}{75} & Murni & 19,13 & 22,30 & 21,09 & $20,84 a$ \\
\hline & Biochar $10 \%$ & 18,64 & 19,84 & 20,12 & $19,53 \mathrm{a}$ \\
\hline & Biochar 20\% & 18,84 & 19,58 & 20,92 & $19,78 \mathrm{a}$ \\
\hline & Rerata & $18,87 \mathrm{~b}$ & $20,57 \mathrm{a}$ & $20,71 \mathrm{a}$ & $(-)$ \\
\hline & Kontrol & \multicolumn{3}{|c|}{19,34} & \\
\hline
\end{tabular}

Keterangan: Angka pada baris dan kolom yang diikuti huruf sama menunjukkan tidak berbeda pada tingkat nyata ( $\alpha$ ) 5\% menurut uji DMRT. (-) tidak terjadi interaksi antar faktor. $(+)$ terjadi interaksi.

Tabel 3. Berat Volume Tanah $\left(\mathrm{g} / \mathrm{cm}^{3}\right)$

\begin{tabular}{|c|c|c|c|c|c|}
\hline \multirow{2}{*}{$\begin{array}{c}\text { Waktu } \\
\text { Pengamatan } \\
\text { (HST) }\end{array}$} & \multirow{2}{*}{$\begin{array}{l}\text { Residu } \\
\text { Kompos } \\
\text { Biochar }\end{array}$} & \multicolumn{3}{|c|}{ Jenis Teh Kompos } & \multirow[b]{2}{*}{ Rerata } \\
\hline & & Tanpa & Murni & Teh+Biochar & \\
\hline \multirow{5}{*}{0} & Murni & 1,78 & 1,67 & 1,74 & $1,73 a$ \\
\hline & Biochar $10 \%$ & 1,57 & 1,57 & 1,56 & $1,56 \mathrm{~b}$ \\
\hline & Biochar $20 \%$ & 1,54 & 1,48 & 1,44 & $1,49 \mathrm{~b}$ \\
\hline & Rerata & $1,63 \mathrm{a}$ & $1,57 \mathrm{a}$ & $1,58 \mathrm{a}$ & $(-)$ \\
\hline & Kontrol & \multicolumn{3}{|c|}{1,51} & \\
\hline \multirow{5}{*}{15} & Murni & 1,59 & 1,64 & 1,62 & $1,62 \mathrm{a}$ \\
\hline & Biochar $10 \%$ & 1,61 & 1,69 & 1,55 & $1,62 \mathrm{a}$ \\
\hline & Biochar $20 \%$ & 1,58 & 1,50 & 1,62 & $1,57 \mathrm{a}$ \\
\hline & Rerata & $1,59 \mathrm{a}$ & $1,61 \mathrm{a}$ & $1,60 \mathrm{a}$ & $(-)$ \\
\hline & Kontrol & \multicolumn{3}{|c|}{1,58} & \\
\hline \multirow{5}{*}{45} & (Murni) & 1,63 & 1,56 & 1,56 & $1,58 \mathrm{a}$ \\
\hline & Biochar $10 \%$ & 1,63 & 1,56 & 1,65 & $1,61 \mathrm{a}$ \\
\hline & Biochar $20 \%$ & 1,58 & 1,61 & 1,61 & $1,60 \mathrm{a}$ \\
\hline & Rerata & $1,61 \mathrm{a}$ & $1,57 \mathrm{a}$ & $1,60 \mathrm{a}$ & $(-)$ \\
\hline & Kontrol & \multicolumn{3}{|c|}{1,61} & \\
\hline \multirow{5}{*}{75} & Murni & 1,54 & 1,47 & 1,57 & $1,53 a$ \\
\hline & Biochar $10 \%$ & 1,65 & 1,64 & 1,58 & $1,62 \mathrm{a}$ \\
\hline & Biochar $20 \%$ & 1,54 & 1,48 & 1,61 & $1,54 \mathrm{a}$ \\
\hline & Rerata & $1,58 \mathrm{a}$ & $1,53 \mathrm{a}$ & $1,58 \mathrm{a}$ & $(-)$ \\
\hline & Kontrol & \multicolumn{3}{|c|}{1,62} & \\
\hline
\end{tabular}

Keterangan:Angka pada baris dan kolom yang diikuti huruf sama menunjukkan tidak berbeda pada tingkat nyata( $\alpha$ ) $5 \%$ menurut uji DMRT. (-) tidak terjadi interaksi antar faktor.

\section{pH Tanah}

Hasil sidik ragam (anova) menujukkan tidak terjadi interaksi antara perlakuan residu kompos biochar dan aplikasi teh kompos pada pengamatan $\mathrm{pH}$ tanah. Perlakuan residu kompos biochar $10 \%$ menghasilkan $\mathrm{pH}$ tanah terendah $(6,39)$ namun tidak berbeda nyata antara aras perlakuan lainnya. Sedangkan petak yang diberikan perlakuan teh kompos murni menghasilkan $\mathrm{pH}$ tanah terendah $(6,40)$ namun tidak berbeda nyata dengan aras perlakuan lainnya pada waktu pengamatan -1 HST. Pada waktu pengamatan 15 HST, Pengaruh utama perlakuan tanpa residu kompos biochar mampu menurunkan $\mathrm{pH}$ tanah yaitu $(6,14)$ namun tidak ada beda nyata antara aras peralakuan. Petak yang diberi perlakuan Aplikasi teh kompos + biochar memiliki nilai $\mathrm{pH}$ tanah terendah $(6,13)$ namun tidak berbeda nyata antara perlakuan. Waktu pengamatan 45 HST, menunjukkan bahwa pengaruh utama perlakuan aging biochar $10 \%$ dalam kompos menghasilkan nilai $\mathrm{pH}$ tanah paling rendah $(6,40)$ namun tidak ada beda nyata antara aras perlakuan. Petak yang diberi perlakuan aplikasi teh kompos + biochar menghasilkan $\mathrm{pH}$ tanah paling rendah $(6,40)$ namun tidak ada beda nyata anatara perlakuan. Sedangkan pada waktu pengamatan 75 HST, Pengaruh utama perlakuan residu kompos biochar $10 \%$ menghasilkan $\mathrm{pH}$ tanah paling rendah $(6,36)$ namun tidak berbeda nyata antara aras perlakaun. Sedangkan petak yang diberi perlakuan aplikasi teh kompos + biochar memiliki nilai $\mathrm{pH}$ tanah paling rendah $(6,35)$. walaupun tidak terjadi interaksi antara kombinasi perlakuan, namun kombinasi perlakuan residu kompos biochar $10 \%$ dan aplikasi teh kompos murni menghasilkan $\mathrm{pH}$ tanah paling rendah, tertinggi dihasilkan oleh kontrol (Tabel 4).
Tabel 4. pH tanah

\begin{tabular}{|c|c|c|c|c|c|}
\hline \multirow{2}{*}{$\begin{array}{c}\text { Waktu } \\
\text { Pengamatan } \\
\text { (HST) }\end{array}$} & \multirow{2}{*}{$\begin{array}{c}\text { Residu Kompos } \\
\text { Biochar }\end{array}$} & \multicolumn{3}{|c|}{ Jenis Teh Kompos } & \multirow[b]{2}{*}{ Rerata } \\
\hline & & Tanpa & Murni & Teh+Biochar & \\
\hline \multirow{5}{*}{0} & Murni & 6,45 & 6,38 & 6,37 & $6,40 \mathrm{a}$ \\
\hline & Biochar 10\% & 6,39 & 6,41 & 6,37 & $6,39 \mathrm{a}$ \\
\hline & Biochar 20\% & 6,43 & 6,41 & 6,49 & $6,44 a$ \\
\hline & Rerata & $6,42 \mathrm{a}$ & $6,40 \mathrm{a}$ & $6,41 \mathrm{a}$ & $(-)$ \\
\hline & Kontrol & \multicolumn{3}{|c|}{6,37} & \\
\hline \multirow{5}{*}{15} & Murni & 6,13 & 6,17 & 6,14 & $6,14 a$ \\
\hline & Biochar 10\% & 6,15 & 6,18 & 6,12 & $6,15 \mathrm{a}$ \\
\hline & Biochar $20 \%$ & 6,15 & 6,16 & 6,14 & $6,15 \mathrm{a}$ \\
\hline & Rerata & $6,14 a$ & $6,17 \mathrm{a}$ & $6,13 a$ & $(-)$ \\
\hline & Kontrol & \multicolumn{3}{|c|}{6,14} & \\
\hline \multirow{5}{*}{45} & (Murni) & 6,40 & 6,40 & 6,41 & $6,40 \mathrm{a}$ \\
\hline & Biochar $10 \%$ & 6,41 & 6,40 & 6,41 & $6,40 \mathrm{a}$ \\
\hline & Biochar 20\% & 6,41 & 6,39 & 6,39 & $6,40 \mathrm{a}$ \\
\hline & Rerata & $6,41 \mathrm{a}$ & $6,40 \mathrm{a}$ & $6,40 \mathrm{a}$ & $(-)$ \\
\hline & Kontrol & \multicolumn{3}{|c|}{6,40} & \\
\hline \multirow{5}{*}{75} & Murni & 6,38 & 6,38 & 6,35 & $6,37 a$ \\
\hline & Biochar $10 \%$ & 6,36 & 6,38 & 6,36 & $6,37 a$ \\
\hline & Biochar $20 \%$ & 6,36 & 6,37 & 6,35 & $6,36 \mathrm{a}$ \\
\hline & Rerata & $6,37 \mathrm{a}$ & $6,38 \mathrm{a}$ & $6,35 \mathrm{a}$ & $(-)$ \\
\hline & Kontrol & \multicolumn{3}{|c|}{6,39} & \\
\hline
\end{tabular}

Keterangan: Angka pada baris dan kolom yang diikuti huruf sama menunjukkan tidak

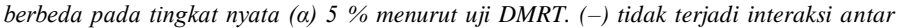
faktor.

\section{Daya Hantar Listrik}

Hasil sidik ragam (anova) menujukkan tidak terjadi interaksi antara perlakuan residu kompos biochar dan aplikasi teh kompos pada pengamatan daya hantar listrik tanah. Perlakuan tanpa residu kompos biochar menghasilkan DHL tanah tertinggi $\left(217,44 \mu / \mathrm{cm}^{2}\right)$ namun tidak berbeda nyata antara aras perlakuan lainnya. Sedangkan petak yang diberikan perlakuan teh kompos murni menghasilkan DHL tanah tertinggi $\left(208,30 \mu / \mathrm{cm}^{2}\right)$ namun tidak berbeda nyata dengan aras perlakuan lainnya pada waktu pengamatan -1 HST. Pada waktu pengamatan 15 HST, Pengaruh utama perlakuan residu kompos biochar $20 \%$ menghasilkan DHL tanah tertinggi yaitu $\left(313,96 \mu / \mathrm{cm}^{2}\right)$ namun tidak ada beda nyata antara aras perlakuan. Petak yang diberi perlakuan aplikasi teh kompos murni memiliki nilai DHL tanah tertinggi $\left(327,22 \mu / \mathrm{cm}^{2}\right)$ dan berbeda nyata antara perlakuan. Waktu pengamatan 45 HST, menunjukkan bahwa Pengaruh utama perlakuan residu kompos biochar $20 \%$ menghasilkan nilai DHL tanah paling tinggi $\left(356,56 \mu / \mathrm{cm}^{2}\right)$ namun tidak ada beda nyata antara aras perlakuan. Petak yang diberi perlakuan aplikasi teh kompos murni menghasilkan DHL tanah paling tinggi $\left(362,81 \mu / \mathrm{cm}^{2}\right)$ namun tidak ada beda nyata antara perlakuan. Sedangkan pada waktu pengamatan 75 HST, Pengaruh utama perlakuan residu kompos biochar $10 \%$ menghasilkan DHL tanah paling tinggi $\left(340,30 \mu / \mathrm{cm}^{2}\right)$ namun tidak berbeda nyata antara aras perlakuan. Sedangkan petak yang diberi tanpa perlakuan aplikasi teh kompos memiliki nilai DHL tanah paling tertinggi $\left(337,19 \mu / \mathrm{cm}^{2}\right)$. Walaupun tidak terjadi interaksi antara kombinasi perlakuan, namun kombinasi perlakuan residu kompos biochar $20 \%$ dan aplikasi teh kompos murni menghasilkan DHL tanah paling tertinggi (Tabel. 5).

\section{Jumlah Daun}

Hasil sidik ragam ((anova)) menujukkan tidak terjadi interaksi antara perlakuan residu kompos biochar dan aplikasi teh kompos pada pengamatan jumlah daun tanaman. Perlakuan residu kompos biochar $20 \%$ menghasilkan jumlah daun tanaman paling banyak (4,09 helai) namun tidak berbeda nyata antara aras perlakuan lainnya. Sedangkan petak yang diberi perlakuan tanpa teh kompos menghasilkan jumlah daun terbanyak (4,02 helai) namun tidak berbeda nyata dengan aras perlakuan lainnya pada waktu pengamatan $15 \mathrm{HST}$. Pengaruh utama perlakuan residu kompos biochar $10 \%$ menghasilkan jumlah daun tanaman tertinggi yaitu (5,91 helai) namun tidak berbeda nyata antara aras perlakuan. Petak yang diberi perlakuan aplikasi teh kompos murni memiliki nilai jumlah daun tertinggi $(5,87$ helai) namun tidak berbeda nyata antara perlakuan pada waktu pengamatan $30 \mathrm{HST}$. Waktu pengamatan $45 \mathrm{HST}$, menunjukkan bahwa Pengaruh utama perlakuan residu kompos biochar $20 \%$ menghasilkan nilai jumlah daun paling tinggi ( 7,76 helai) namun tidak ada beda nyata antara aras perlakuan. Petak yang diberi perlakuan aplikasi teh kompos + biochar menghasilkan jumlah daun tanaman paling tinggi (7,76 helai) namun tidak ada beda nyata antara perlakuan. Sedangkan pada waktu pengamatan 75 HST, Pengaruh utama perlakuan residu kompos biochar $20 \%$ menghasilkan jumlah daun tanaman paling banyak (9,76 helai) namun tidak berbeda nyata antara aras perlakuan. Sedangkan petak yang diberi perlakuan aplikasi teh kompos + biochar memiliki nilai jumlah daun tanaman tertinggi $(9,67)$. Walaupun tidak terjadi interaksi antara kombinasi perlakuan, namun kombinasi perlakuan residu kompos biochar $20 \%$ dan aplikasi teh kompos + biochar menghasilkan jumlah daun tanaman paling banyak dibandingkan dengan kontrol (Tabel 6.) 


\section{Luas Daun}

Hasil sidik ragam (anova) menunjukkan tidak terjadi interaksi antara perlakuan, walaupun demikian kombinasi perlakuan residu kompos biochar 20 $\%$ dan aplikasi teh kompos murni memiliki indeks luas daun terbesar $(7,87)$ Pengaruh utama perlakuan residu kompos biochar $20 \%$ menghasilkan nilai indeks luas daun tertinggi $(6,74)$ namun tidak berbeda nyata antara aras perlakuan lainnya. Pengaruh utama perlakuan aplikasi teh kompos murni menunjukkan indeks luas daun tanaman tertinggi $(6,90)$ namun tidak berbeda nyata dengan aras perlakuan lainnya. Bila dibandingkan dengan kontrol indeks luas daun yang dihasilkan oleh kontrol menghasilkan nilai paling tinggi dibandingkan dengan perlakuan (Tabel 7).

Tabel 5. Daya Hantar Listrik

\begin{tabular}{|c|c|c|c|c|c|}
\hline \multirow{2}{*}{$\begin{array}{c}\text { Waktu } \\
\text { Pengamatan } \\
\text { (HST) } \\
\end{array}$} & \multirow{2}{*}{$\begin{array}{c}\text { Residu Komps } \\
\text { Biochar }\end{array}$} & \multicolumn{3}{|c|}{ Jenis Teh Kompos } & \multirow[b]{2}{*}{ Rerata } \\
\hline & & Tanpa & Murni & Teh+Biochar & \\
\hline \multirow{5}{*}{0} & Murni & 242,00 & 223,33 & 187,00 & $217,44 a$ \\
\hline & Biochar $10 \%$ & 190,33 & 205,56 & 192,11 & $196,00 \mathrm{a}$ \\
\hline & Biochar $20 \%$ & 192,56 & 195,11 & 200,89 & $196,19 \mathrm{a}$ \\
\hline & Rerata & $208,3 \mathrm{a}$ & $208,00 \mathrm{a}$ & $193,33 a$ & $(-)$ \\
\hline & Kontrol & & 196,67 & & \\
\hline \multirow{5}{*}{15} & Murni & 251,78 & 310,44 & 305,11 & $289,11 \mathrm{a}$ \\
\hline & Biochar $10 \%$ & 256,11 & 363,00 & 246,56 & $288,56 \mathrm{a}$ \\
\hline & Biochar $20 \%$ & 300,44 & 308,22 & 333,22 & $313,96 a$ \\
\hline & Rerata & $269,44 \mathrm{~b}$ & $327,22 \mathrm{a}$ & $294,96 \mathrm{ab}$ & $(-)$ \\
\hline & Kontrol & & 283,33 & & \\
\hline \multirow{5}{*}{45} & (Murni) & 342,78 & 375,33 & 351,33 & $356,48 \mathrm{a}$ \\
\hline & Biochar $10 \%$ & 332,67 & 334,44 & 366,67 & $344,59 a$ \\
\hline & Biochar $20 \%$ & 350,00 & 378,67 & 341,00 & $356,56 a$ \\
\hline & Rerata & $341,81 \mathrm{a}$ & $362,81 \mathrm{a}$ & $353,00 \mathrm{a}$ & $(-)$ \\
\hline & Kontrol & & 342,89 & & \\
\hline \multirow{5}{*}{75} & Murni & 330,22 & 336,78 & 330,00 & $332,33 a$ \\
\hline & Biochar $10 \%$ & 350,89 & 336,44 & 333,56 & $340,30 \mathrm{a}$ \\
\hline & Biochar $20 \%$ & 330,44 & 328,44 & 345,33 & $334,74 \mathrm{a}$ \\
\hline & Rerata & $337,19 \mathrm{a}$ & $333,89 \mathrm{a}$ & $336,30 \mathrm{a}$ & $(-)$ \\
\hline & Kontrol & & 357,89 & & \\
\hline
\end{tabular}

Keterangan: Angka pada baris dan kolom yang diikuti huruf sama menunjukkan tidak berbeda pada tingkat nyata ( $\alpha$ ) $5 \%$ menurut uji DMRT. (-) tidak terjadi interaksi antar faktor.

\section{Tabel6. Jumlah Daun}

\begin{tabular}{|c|c|c|c|c|c|}
\hline \multirow{2}{*}{$\begin{array}{c}\text { Waktu } \\
\text { Pengamatan } \\
\text { (HST) }\end{array}$} & \multirow{2}{*}{$\begin{array}{c}\text { Residukompos } \\
\text { Biochar }\end{array}$} & \multicolumn{3}{|c|}{ Jenis Teh Kompos } & \multirow[b]{2}{*}{ Rerata } \\
\hline & & Tanpa & Murni & Teh+Biochar & \\
\hline \multirow{5}{*}{15} & Murni & 3,93 & 4,00 & 3,87 & $3,93 \mathrm{a}$ \\
\hline & Biochar $10 \%$ & 3,93 & 4,00 & 3,80 & $3,91 \mathrm{a}$ \\
\hline & Biochar $20 \%$ & 4,20 & 4,00 & 4,07 & $4,09 \mathrm{a}$ \\
\hline & Rerata & $4,02 \mathrm{a}$ & $4,00 \mathrm{a}$ & $3,91 \mathrm{a}$ & $(-)$ \\
\hline & Kontrol & \multicolumn{3}{|c|}{4,07} & \\
\hline \multirow{5}{*}{30} & Murni & 5,60 & 5,73 & 5,87 & $5,73 \mathrm{a}$ \\
\hline & Biochar $10 \%$ & 5,87 & 6,13 & 5,73 & $5,91 \mathrm{a}$ \\
\hline & Biochar $20 \%$ & 5,87 & 5,73 & 5,87 & $5,82 \mathrm{a}$ \\
\hline & Rerata & $5,78 \mathrm{a}$ & $5,87 \mathrm{a}$ & $5,82 \mathrm{a}$ & $(-)$ \\
\hline & Kontrol & \multicolumn{3}{|c|}{6,00} & \\
\hline \multirow{5}{*}{45} & (Murni) & 7,53 & 7,47 & 7,47 & $7,49 \mathrm{a}$ \\
\hline & Biochar $10 \%$ & 7,33 & 8,07 & 7,47 & $7,62 \mathrm{a}$ \\
\hline & Biochar $20 \%$ & 7,73 & 7,47 & 8,07 & $7,76 \mathrm{a}$ \\
\hline & Rerata & $7,53 \mathrm{a}$ & $7,67 \mathrm{a}$ & $7,67 \mathrm{a}$ & $(-)$ \\
\hline & Kontrol & \multicolumn{3}{|c|}{8,00} & \\
\hline \multirow{5}{*}{75} & Murni & 9,53 & 9,47 & 9,47 & $9,49 \mathrm{a}$ \\
\hline & Biochar $10 \%$ & 9,33 & 10,07 & 9,47 & $9,62 \mathrm{a}$ \\
\hline & Biochar $20 \%$ & 9,73 & 9,47 & 10,07 & $9,76 \mathrm{a}$ \\
\hline & Rerata & $9,53 \mathrm{a}$ & $9,67 \mathrm{a}$ & $9,67 \mathrm{a}$ & $(-)$ \\
\hline & Kontrol & \multicolumn{3}{|c|}{9,93} & \\
\hline
\end{tabular}

Keterangan: Angka pada baris dan kolom yang diikuti huruf sama menunjukkan tidak berbeda pada tingkat nyata ( $\alpha$ ) $5 \%$ menurut uji DMRT. (-) tidak terjadi interaksi antar faktor.

Tabel 7. Luas daun

\begin{tabular}{ccccc}
\hline Residu Kompos & \multicolumn{3}{c}{ Jenis Teh Kompos } & \multirow{2}{*}{ Rerata } \\
\cline { 2 - 4 } Biochar & Tanpa & Murni & Teh+Biochar & \\
\hline Murni & 5,92 & 7,46 & 4,46 & $5,95 \mathrm{a}$ \\
Biochar 10\% & 4,61 & 5,35 & 6,52 & $5,50 \mathrm{a}$ \\
Biochar 20\% & 5,49 & 7,87 & 6,86 & $6,74 \mathrm{a}$ \\
\hline Rerata & $5,34 \mathrm{a}$ & $6,90 \mathrm{a}$ & $5,95 \mathrm{a}$ & $(-)$ \\
\hline Kontrol & \multicolumn{5}{c}{11,56} \\
\hline
\end{tabular}

Keterangan: Angka pada baris dan kolom yang diikuti huruf sama menunjukkan tidak berbeda pada tingkat nyata ( $\alpha$ ) $5 \%$ menurut uji DMRT. (-) tidak terjadi interaksi antar faktor.

\section{Jumlah Umbi Per Petak}

Hasil sidik ragam (anova) menunjukkan terjadi interaksi antara kombinasi perlakuan residu kompos biochar dan perlakuan aplikasi jenis teh kompos, kombinasi perlakuan residu kompos biochar $20 \%$ dan perlakuan aplikasi teh kompos murni menghasilkan jumlah jumbi per petak terbanyak $(1,95 \mathrm{~g})$, sedangkan terendah dihasilkan oleh kombinasi perlakuan residu kompos biochar $10 \%$ dan perlakuan aplikasi teh kompos murni dengan nilai $(141,33)$ dan berbeda nyata antara kombinasi perlakuan (Tabel 8)

Tabel 8. Jumlah Umbi Per Petak

\begin{tabular}{ccccc}
\hline Residu Kompos & \multicolumn{4}{c}{ Jenis Teh Kompos } \\
\cline { 2 - 4 } Biochar & Tanpa & Murni & Teh + Biochar & \\
\hline Murni & $1,90 \mathrm{ab}$ & $1,95 \mathrm{a}$ & $1,91 \mathrm{ab}$ & 1,91 \\
Biochar $10 \%$ & $1,95 \mathrm{a}$ & $1,88 \mathrm{~b}$ & $1,94 \mathrm{ab}$ & 1,92 \\
Biochar $20 \%$ & $1,89 \mathrm{ab}$ & $1,95 \mathrm{a}$ & $1,92 \mathrm{ab}$ & 1,92 \\
\hline Rerata & 1,91 & 1,93 & 1,92 & $(+)$ \\
\hline Kontrol & \multicolumn{5}{c}{$1,91 \mathrm{ab}$} \\
\hline
\end{tabular}

Keterangan: Angka pada baris dan kolom yang diikuti huruf sama menunjukkan tidak

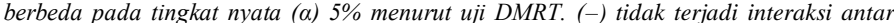
faktor. (+) terjadi interaksi.

\section{Jumlah Umbi Siung Tunggal Per Petak}

Hasil sidik ragam (anova) menunjukkan tidak terjadi interaksi antara perlakuan, walaupun demikian kombinasi tanpa perlakuan residu kompos biochar dan aplikasi teh kompos + biochar memiliki jumlah umbi siung tunggal per petak terbesar $(1,44)$. Pengaruh utama tanpa perlakuan residu kompos biochar menghasilkan nilai jumlah umbi siung tunggal per petak tertinggi $(1,29)$ namun tidak berbeda nyata antara aras perlakuan lainnya. Pengaruh utama perlakuan aplikasi teh kompos + biochar menunjukkan jumlah umbi siung tunggal tanaman per petak tertinggi $(1,34)$ namun tidak berbeda nyata dengan aras perlakuan lainnya. Rerata perlakuan menunjukkan pembentukkan umbi siung tunggal per petak terbanyak dibandingkan dengan control (Tabel 9)

Tabel 9. Jumlah Umbi Siung Tunggal Per Petak

\begin{tabular}{ccccc}
\hline Residu K ompos & \multicolumn{3}{c}{ Jenis Teh Kompos } & \multirow{2}{*}{ Rerata } \\
\cline { 2 - 4 } Biochar & Tanpa & Murni & Teh+Biochar & \\
\hline Murni & 1,18 & 1,40 & 1,28 & $1,29 \mathrm{a}$ \\
Biochar 10 $\%$ & 1,24 & 1,06 & 1,44 & $124 \mathrm{a}$ \\
Biochar 20\% & 1,18 & 1,20 & 1,31 & $1,23 \mathrm{a}$ \\
\hline Rerata & $1,20 \mathrm{a}$ & $1,22 \mathrm{a}$ & $1,34 \mathrm{a}$ & $(-)$ \\
\hline Kontrol & \multicolumn{5}{c}{} \\
\hline
\end{tabular}

Keterangan: Angka pada baris dan kolom yang diikuti huruf sama menunjukkan tidak berbeda pada tingkat nyata $(\alpha)$ 5\% menurut uji DMRT. (-) tidak terjadi interaksi antar faktor.

\section{Jumlah Umbi Siung Majemuk Per Petak}

Hasil sidik ragam (anova) menunjukkan tidak terjadi interaksi antara perlakuan, walaupun demikian kombinasi perlakuan residu kompos biochar 10 $\%$ dan aplikasi teh kompos + biochar memiliki jumlah umbi siung majemuk per petak terendah $(0,50)$. Pengaruh utama tanpa perlakuan residu kompos biochar menghasilkan nilai jumlah umbi siung majemuk per petak terendah $(0,63)$ namun tidak berbeda nyata antara aras perlakuan lainnya. Pengaruh utama perlakuan aplikasi teh kompos + biochar menunjukkan jumlah umbi siung majemuk tanaman per petak terendah $(0,58)$ namun tidak berbeda nyata dengan aras perlakuan lainnya. Rerata perlakuan menunjukkan pembentukkan umbi siung majemuk per petak terendah dibandingkan dengan control (Tabel 10)

Tabel 10. Jumlah Umbi Siung Majemuk Per Petak

\begin{tabular}{ccccc}
\hline Residu Kompos & \multicolumn{4}{c}{ Jenis Teh Kompos } \\
Biochar & Tanpa & Murni & Teh+Biochar & Rerata \\
\hline Murni & 0,72 & 0,55 & 0,62 & $0,63 \mathrm{a}$ \\
Biochar $10 \%$ & 0,76 & 0,83 & 0,50 & $0,69 \mathrm{a}$ \\
Biochar $20 \%$ & 0,27 & 0,75 & 0,61 & $0,69 \mathrm{a}$ \\
\hline Rerata & $0,73 \mathrm{a}$ & $0,71 \mathrm{a}$ & $0,58 \mathrm{a}$ & $(-)$ \\
\hline Kontrol & 1,18 \\
\hline
\end{tabular}

Keterangan: Angka pada baris dan kolom yang diikuti huruf sama menunjukkan tidak berbeda pada tingkat nyata ( $\alpha$ ) $5 \%$ menurut uji DMRT. (-) tidak terjadi interaksi antar faktor.

\section{Bobot Panen Umbi Siung Tunggal Per Petak}

Hasil sidik ragam (anova) menunjukkan tidak terjadi interaksi antara perlakuan, walaupun demikian kombinasi tanpa perlakuan residu kompos biochar dan aplikasi teh kompos murni memiliki berat panen umbi siung tunggal per petak terberat $(1,06 \mathrm{~g})$. Pengaruh utama tanpa perlakuan residu kompos biochar menghasilkan nilai bobot panen umbi siung tunggal per petak tertinggi $(0,92 \mathrm{~g})$ namun tidak berbeda nyata antara aras perlakuan lainnya. Pengaruh utama perlakuan aplikasi teh kompos + biochar menunjukkan bobot panen umbi siung tunggal tanaman per petak terberat $(0,97 \mathrm{~g})$ namun tidak berbeda nyata denganaras perlakuan lainnya. Rerata perlakuan menunjukkan berat panen umbi siung tunggal per petak terberat dibandingkan dengan control (Tabel 11). 
Tabel 11. Bobot Panen Umbi Siung Tunggal Per Petak

\begin{tabular}{ccccc}
\hline Residu Kompos & \multicolumn{3}{c}{ Jenis Teh Kompos } & \multirow{2}{*}{ Rerata } \\
\cline { 2 - 4 } Biochar & Tanpa & Murni & Teh+Biochar & \\
\hline Murni & 0,84 & 1,06 & 0,86 & $0,92 \mathrm{a}$ \\
Biochar 10\% & 0,88 & 0,74 & 0,96 & $0,86 \mathrm{a}$ \\
Biochar 20\% & 0,82 & 0,81 & 0,98 & $0,87 \mathrm{a}$ \\
\hline Rerata & $0,85 \mathrm{a}$ & $0,87 \mathrm{a}$ & $0,97 \mathrm{a}$ & $(-)$ \\
\hline Kontrol & \multicolumn{5}{c}{0,71} \\
\hline
\end{tabular}

Keterangan: Angka pada baris dan kolom yang diikuti huruf sama menunjukkan tidak berbeda pada tingkat nyata (a) $5 \%$ menurut uji DMRT. (-) tidak terjadi interaksi antar faktor.

\section{Bobot Panen Siung Majemuk Per Petak}

Hasil sidik ragam (anova) menunjukkan tidak terjadi interaksi antara perlakuan, walaupun demikian kombinasi perlakuan residu kompos biochar 10 $\%$ dan aplikasi teh kompos murni memiliki berat panen umbi siung majemuk per petak terberat $(1,01 \mathrm{~g})$. Pengaruh utama perlakuan residu kompos biochar $20 \%$ menghasilkan nilai bobot panen umbi siung majemuk per petak tertinggi $(0,86 \mathrm{~g})$ namun tidak berbeda nyata antara aras perlakuan lainnya. Pengaruh utama perlakuan aplikasi teh kompos murni menunjukkan bobot panen umbi siung majemuk tanaman per petak terberat $(0,87 \mathrm{~g})$ namun tidak berbeda nyata dengan aras perlakuan lainnya. Rerata perlakuan menunjukkan bobot panen umbi siung majemuk per petak terberat dihasilkan oleh kontrol (Tabel 12).

Tabel 12. Bobot Panen Siung Majemuk Per Petak

\begin{tabular}{ccccc}
\hline Residu Kompos & \multicolumn{3}{c}{ Jenis Teh Kompos } & \multirow{2}{*}{ Rerata } \\
\cline { 2 - 4 } Biochar & Tanpa & Murni & Teh+Biochar & \\
\hline Murni & 0,78 & 0,72 & 0,86 & $0,78 \mathrm{a}$ \\
Biochar $10 \%$ & 0,76 & 1,01 & 0,59 & $0,79 \mathrm{a}$ \\
Biochar 20\% & 0,80 & 0,87 & 0,85 & $0,86 \mathrm{a}$ \\
\hline Rerata & $0,80 \mathrm{a}$ & $0,87 \mathrm{a}$ & $0,76 \mathrm{a}$ & $(-)$ \\
\hline Kontrol & \multicolumn{5}{c}{} \\
\hline
\end{tabular}

Keterangan:Angka pada baris dan kolom yang diikuti huruf sama menunjukkan tidak berbeda pada tingkat nyata( $\alpha$ ) $5 \%$ menurut uji DMRT. (-) tidak terjadi interaksi antar faktor.

\section{Bobot Kering Total Umbi Per Petak}

Hasil sidik ragam (anova) menunjukkan tidak terjadi interaksi antara perlakuan, walaupun demikian kombinasi perlakuan residu kompos biochar 10 $\%$ dan perlakun tanpa aplikasi teh kompos memiliki bobot kering umbi per petak terberat $(1,67 \mathrm{~g})$. Pengaruh utama perlakuan residu kompos biochar $10 \%$ menghasilkan nilai bobot kering umbi per petak tertinggi $(1,57 \mathrm{~g})$ namun tidak berbeda nyata antara aras perlakuan lainnya. Pengaruh utama perlakuan aplikasi teh kompos + biochar menunjukkan bobot kering umbi tanaman per petak terberat $(1,56 \mathrm{~g})$ namun tidak berbeda nyata dengan aras perlakuan lainnya. Rerata perlakuan menunjukkan bobot kering umbi per petak terberat dihasilkan oleh kontrol (Tabel 13)

Tabel 13. Bobot Kering Total Umbi Per Petak

\begin{tabular}{ccccc}
\hline Residu Kompos & \multicolumn{3}{c}{ Jenis Teh Kompos } \\
\cline { 2 - 4 } Biochar & Tanpa & Murni & Teh + Biochar & \\
\hline Murni & 1,43 & 1,54 & 1.58 & $1,51 \mathrm{a}$ \\
Biochar $10 \%$ & 1,67 & 1,61 & 1,43 & $1,57 \mathrm{a}$ \\
Biochar $20 \%$ & 1,51 & 1,53 & 1,66 & $1,57 \mathrm{a}$ \\
\hline Rerata & $1,54 \mathrm{a}$ & $1,56 \mathrm{a}$ & $1,56 \mathrm{a}$ & $(-)$ \\
\hline Kontrol & \multicolumn{5}{c}{} \\
\hline
\end{tabular}

Keterangan: Angka pada baris dan kolom yang diikuti huruf sama menunjukkan tidak

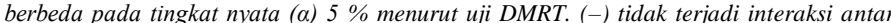
faktor.

\section{Bobot Kering Umbi Siung Tunggal Per Petak}

Hasil sidik ragam (anova) menunjukkan tidak terjadi interaksi antara perlakuan, walaupun demikian kombinasi tanpa perlakuan residu kompos biochar dan aplikasi teh kompos murni memiliki berat kering umbi siung tunggal per petak terberat $(0,93 \mathrm{~g})$. Pengaruh utama perlakuan residu kompos biochar $10 \%$ menghasilkan nilai bobot kering umbi siung tunggal per petak tertinggi $(0,82 \mathrm{~g})$ namun tidak berbeda nyata antara aras perlakuan lainnya. Pengaruh utama perlakuan aplikasi teh kompos + biochar menunjukkan bobot kering umbi siung tunggal tanaman per petak terberat $(0,85 \mathrm{~g})$ namun tidak berbeda nyata denganaras perlakuan lainnya. Rerata perlakuan menunjukkan bobot kering umbi siung tunggal per petak terberat dibandingkan dengan kontrol (Tabel 14).

\section{Bobot Kering Umbi Siung Majemuk Per Petak}

Hasil sidik ragam (anova) menunjukkan tidak terjadi interaksi antara perlakuan, walaupun demikian kombinasi perlakuan residu kompos biochar 10 $\%$ dan aplikasi teh kompos murni memiliki berat kering umbi siung majemuk per petak terberat $(0,93 \mathrm{~g})$. Pengaruh utama perlakuan residu kompos biochar $20 \%$ menghasilkan nilai bobot panen umbi siung majemuk per petak tertinggi $(0,78 \mathrm{~g})$ namun tidak berbeda nyata antara aras perlakuan lainnya. Pengaruh utama tanpa perlakuan aplikasi teh kompos menunjukkan bobot kering umbi siung majemuk tanaman per petak terberat $(0,76 \mathrm{~g})$ namun tidak berbeda nyata dengan aras perlakuan lainnya. Rerata perlakuan menunjukkan bobot kering umbi siung majemuk per petak terberat dihasilkan oleh control (Tabel 15)

Tabel 14. Bobot Kering Umbi Siung Tunggal Per Petak

\begin{tabular}{ccccc}
\hline $\begin{array}{c}\text { Residu Kompos } \\
\text { Biochar }\end{array}$ & Tanpa & Menis Teh Kompos & \multirow{2}{*}{ Rerata } \\
\hline Murni & 0,72 & 0,93 & Teh + Biochar & \\
Biochar 10\% & 0,88 & 0,68 & 0,77 & $0,81 \mathrm{a}$ \\
Biochar 20\% & 0,71 & 0,78 & 0,88 & $0,82 \mathrm{a}$ \\
\hline Rerata & $0,77 \mathrm{a}$ & $0,80 \mathrm{a}$ & $0,85 \mathrm{a}$ & $(-)$ \\
\hline
\end{tabular}

Kontrol

0,65

Keterangan: Angka pada baris dan kolom yang diikuti huruf sama menunjukkan tidak berbeda pada tingkat nyata (a) $5 \%$ menurut uji DMRT. (-) tidak terjadi interaksi antar faktor

Tabel 15. Bobot Kering Umbi Siung Majemuk Per Petak

\begin{tabular}{ccccc}
\hline Residu Kompos & \multicolumn{3}{c}{ Jenis Teh Kompos } & \multirow{2}{*}{ Rerata } \\
\cline { 2 - 4 } Biochar & Tanpa & Murni & Teh + Biochar & \\
\hline Murni & 0,70 & 0,60 & 0,81 & $0,70 \mathrm{a}$ \\
Biochar 10 \% & 0,78 & 0,93 & 0,54 & $0,78 \mathrm{a}$ \\
Biochar 20 \% & 0,80 & 0,75 & 0,67 & $0,78 \mathrm{a}$ \\
\hline Rerata & $0,76 \mathrm{a}$ & $0,76 \mathrm{a}$ & $0,71 \mathrm{a}$ & $(-)$ \\
\hline Kontrol & & 0,78 &
\end{tabular}

Keterangan: Angka pada baris dan kolom yang diikuti huruf sama menunjukkan tidak berbeda pada tingkat nyata ( $\alpha$ ) $5 \%$ menurut uji DMRT. (-) tidak terjadi interaksi antar faktor.

\section{Bobot Kering Umbi Siung Tunggal Per Tanaman}

Hasil sidik ragam (anova) menunjukkan tidak terjadi interaksi antara perlakuan, walaupun demikian kombinasi tanpa perlakuan residu kompos biochar dan aplikasi teh kompos murni memiliki bobot kering umbi siung tunggal per tanaman terberat $(1,40 \mathrm{~g})$. Pengaruh utama perlakuan residu kompos biochar $20 \%$ menghasilkan nilai bobot kering umbi siung tunggal per tanaman tertinggi $(1,25 \mathrm{~g})$ namun tidak berbeda nyata antara aras perlakuan lainnya. Pengaruh utama perlakuan aplikasi teh kompos murni menunjukkan bobot kering umbi siung tunggal per tanaman terberat $(1,25 \mathrm{~g})$ namun tidak berbeda nyata dengan aras perlakuan lainnya. Rerata perlakuan menunjukkan bobot kering umbi siung tunggal per tanaman terberat dibandingkan dengan control (Tabel 16).

Tabel 16. Bobot Kering Umbi Siung Tunggal Per Tanaman

\begin{tabular}{ccccc}
\hline Residu Kompos & \multicolumn{3}{c}{ Jenis Teh Kompos } & \multirow{2}{*}{ Rerata } \\
\cline { 2 - 4 } Biochar & Tanpa & Murni & Teh+Biochar & \\
\hline Murni & 1,09 & 1,40 & 1,16 & $1,22 \mathrm{a}$ \\
Biochar 10\% & 1,32 & 1,02 & 1,17 & $1,17 \mathrm{a}$ \\
Biochar 20\% & 1,07 & 1,34 & 1,33 & $1,25 \mathrm{a}$ \\
\hline Rerata & $1,16 \mathrm{a}$ & $1,25 \mathrm{a}$ & $1,22 \mathrm{a}$ & $(-)$ \\
\hline Kontrol & \multicolumn{5}{c}{0,98}
\end{tabular}

Keterangan: Angka pada baris dan kolom yang diikuti huruf sama menunjukkan tidak berbeda pada tingkat nyata $(\alpha) 5 \%$ menurut uji DMRT. (-) tidak terjadi interaksi antar faktor.

\section{Bobot Kering Umbi Siung Majemuk Per Tanaman}

Hasil sidik ragam (anova) menunjukkan tidak terjadi interaksi antara kombinasi perlakuan residu kompos biochar $10 \%$ dan aplikasi teh kompos murni memiliki berat kering umbi siung majemuk per tanaman terberat $(2,78$ g). Pengaruh utama perlakuan residu kompos biochar $10 \%$ menghasilkan nilai bobot kering umbi siung majemuk per tanaman tertinggi $(2,46 \mathrm{~g})$ namun tidak berbeda nyata antara aras perlakuan lainnya. Pengaruh utama perlakuan aplikasi teh kompos + biochar menunjukkan bobot kering umbi siung majemuk per tanaman terberat $(2,34 \mathrm{~g})$ namun tidak berbeda nyata dengan aras perlakuan lainnya. Rerata perlakuan menunjukkan bobot kering umbi siung majemuk per tanaman terberat dihasilkan oleh kontrol (Tabel 17).

Tabel 17. Bobot Kering Umbi Siung Majemuk Per Tanaman

\begin{tabular}{ccccc}
\hline Residu Kompos & \multicolumn{3}{c}{ Jenis Teh Kompos } & \multirow{2}{*}{ Rerata } \\
\cline { 2 - 4 } Biochar & Tanpa & Murni & Teh + Biochar & \\
\hline Murni & 2,11 & 1,80 & 2,43 & $2,11 \mathrm{a}$ \\
Biochar 10 \% & 2,35 & 2,78 & 2,25 & $2,46 \mathrm{a}$ \\
Biochar 20\% & 2,40 & 1,61 & 2,34 & $2,12 \mathrm{a}$ \\
\hline Rerata & $2,29 \mathrm{a}$ & $2,06 \mathrm{a}$ & $2,34 \mathrm{a}$ & $(-)$ \\
\hline Kontrol & \multicolumn{5}{c}{} \\
\hline
\end{tabular}

Keterangan: Angka pada baris dan kolom yang diikuti huruf sama menunjukkan tidak berbeda pada tingkat nyata (a) $5 \%$ menurut uji DMRT. (-) tidak terjadi interaksi antar faktor.

\section{Bobot Kering Berangkasan}

Hasil sidik ragam (anova) menunjukkan tidak terjadi interaksi antara perlakuan, walaupun demikian kombinasi perlakuan residu kompos biochar $10 \%$ dan aplikasi teh kompos + biochar memiliki bobot kering berangkasan terendah $(23,80 \mathrm{~g})$. Pengaruh utama tanpa perlakuan residu kompos biochar 
menghasilkan nilai bobot kering berangkasan terendah $(25,54 \mathrm{~g})$ namun tidak berbeda nyata antara aras perlakuan lainnya. Pengaruh utama perlakuan aplikasi teh kompos murni menunjukkan bobot kering berangkasan terendah $(25,39 \mathrm{~g})$ namun tidak berbeda nyata dengan aras perlakuan lainnya. Rerata perlakuan menunjukkan bobot kering tanaman terendah dibanding kontrol (Tabel 18).

Tabel 18. Bobot Kering Berangkasan

\begin{tabular}{ccccc}
\hline Residu Kompos & \multicolumn{3}{c}{ Jenis Teh Kompos } & \multirow{2}{*}{ Rerata } \\
\cline { 2 - 4 } Biochar & Tanpa & Murni & Teh+Biochar & \\
\hline Murni & 24,13 & 24,77 & 27,73 & 25,54 a \\
Biochar 10\% & 28,87 & 26,90 & 23,80 & 26,52 a \\
Biochar 20\% & 24,03 & 24,50 & 29,87 & 26,13 a \\
\hline Rerata & 25,68 a & 25,39 a & 27,13 a & $(-)$ \\
\hline
\end{tabular}

Kontrol 26,90

Keterangan: Angka pada baris dan kolom yang diikuti huruf sama menunjukkan tidak

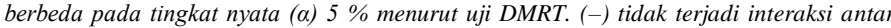
faktor.

\section{Bobot Kering Akar}

Hasil sidik ragam (anova)menunjukkan terjadi interaksi antara kombinasi perlakuan residu kompos biochar dan perlakuan Aplikasi teh kompos pada bobot kering akar. Kombinasih perlakuan residu kompos biochar $20 \%$ dan perlakuan teh kompos murni menghasilkan nilai berat kering akar paling rendah $(3,30$ g).Sedangkan tertinggi dihasilkan oleh kombinasi perlakuan residu kompos biochar $10 \%$ dan perlakuan tanpa Aplikasi teh kompos (6,53 g) (Tabel 19)

Tabel 19. Bobot Kering Akar

\begin{tabular}{ccccc}
\hline Residu Kompos & \multicolumn{4}{c}{ Jenis Teh Kompos } \\
\cline { 2 - 4 } Biochar & Tanpa & Murni & Teh+Biochar & \\
\hline Murni & $4,43 \mathrm{~b}$ & $4,87 \mathrm{ab}$ & $4,67 \mathrm{ab}$ & $4,66 \mathrm{a}$ \\
Biochar 10\% & $6,53 \mathrm{a}$ & $4,57 \mathrm{ab}$ & $3,57 \mathrm{~b}$ & $4,89 \mathrm{a}$ \\
Biochar 20\% & $3,83 \mathrm{~b}$ & $3,30 \mathrm{~b}$ & $4,70 \mathrm{ab}$ & $3,94 \mathrm{a}$ \\
\hline Rerata & $4,93 \mathrm{a}$ & $4,24 \mathrm{a}$ & $4,31 \mathrm{a}$ & $(+)$ \\
\hline Kontrol & \multicolumn{5}{c}{} \\
\hline
\end{tabular}

Keterangan: Angka pada baris dan kolom yang diikuti huruf sama menunjukkan tidak berbeda pada tingkat nyata $(\alpha) 5 \%$ menurut uji DMRT. (-) tidak terjadi interaksi antar faktor $(+)$ terjadi interaksi.

\section{Persentase Pembentukkan Umbi Siung Tunggal Per Petak}

Hasil sidik ragam (anova) menunjukkan tidak terjadi interaksi antara perlakuan, walaupun demikian kombinasi perlakuan residu kompos biochar 20 $\%$ dan perlakuan Aplikasi teh kompos murni menghasilkan persentase pembentukkan umbi siung tunggal per petak tertinggi $(0,99 \%)$. Pengaruh utama perlakuan residu kompos biochar $20 \%$ menghasilkan nilai persentase pembentukkan umbi siung tunggal per petak tertinggi $(0,91 \%)$ namun tidak ada beda nyata antara perlakuan. Sedangkan pengaruh utama perlakuan aplikasi teh kompos murni memiliki peresentase pembentukkan umbi siung tunggal per petak terbanyak $(0,90 \%)$ namun tidak ada beda nyata antara perlakuan (Tabel 20).

Tabel 20. Persentase pembentukkan umbi siung tunggal per petak

\begin{tabular}{ccccc}
\hline Residu & \multicolumn{3}{c}{ Jenis Teh Kompos } & \multirow{2}{*}{ Rerata } \\
\cline { 2 - 4 } KomposBiochar & Tanpa & Murni & Teh + Biochar & \\
\hline Murni & 0,83 & 0,96 & 0,90 & $0,89 \mathrm{a}$ \\
Biochar 10\% & 0,85 & 0,75 & 0,82 & $0,81 \mathrm{a}$ \\
Biochar 20\% & 0,83 & 0,99 & 0,91 & $0,91 \mathrm{a}$ \\
\hline Rerata & $0,83 \mathrm{a}$ & $0,90 \mathrm{a}$ & $0,88 \mathrm{a}$ & $(-)$ \\
\hline Kontrol & \multicolumn{4}{c}{0,76} \\
\hline
\end{tabular}

Keterangan: Angka pada baris dan kolom yang diikuti huruf sama menunjukkan tidak berbeda pada tingkat nyata ( $\alpha$ ) $5 \%$ menurut uji DMRT. (-) tidak terjadi interaksi antar faktor.

\section{Persentase Bobot Umbi Siung Tunggal Per Petak}

Hasil sidik ragam (anova) menunjukkan tidak terjadi interaksi antara perlakuan, walaupun demikian kombinasi perlakuan residu kompos biochar 10 $\%$ dan perlakuan Aplikasi teh kompos + biochar menghasilkan persentase bobot kering umbi siung tunggal tertinggi $(0,84 \%)$. pengaruh tunggal perlakuan residu kompos murni menghasilkan presentase bobot kering umbi siung tunggal per petak tertinggi $(0,71 \%)$ namun tidak ada beda nyata antara kombinasi perlakuan. Sedangkan petak yang diberi perlakuan aplikasi teh komos + biochar menghasilkan presentasi bobot kering umbi siung tunggal per petak tertinggi $(0,73 \%)$ namun tidak ada beda nyata antara kombinasi perlakuan (Tabel 21$)$.

\section{Indeks Panen}

Hasil sidik ragam (anova) menunjukkan tidak terjadi interaksi antara perlakuan, walaupun demikian kombinasi perlakuan residu kompos biochar 20 $\%$ dan aplikasi teh kompos murni memiliki indeks panen tertinggi $(81,38 \%)$. Pengaruh utama perlakuan residu kompos biochar $10 \%$ menghasilkan nilai indeks panen tertinggi $(79,75 \%)$ namun tidak berbeda nyata antara aras perlakuan lainnya. Pengaruh utama perlakuan aplikasi teh kompos murni menunjukkan indeks panen tertinggi $(80,48 \%)$ namun tidak berbeda nyata dengan aras perlakuan lainnya (Tabel 22).

\begin{tabular}{ccccc}
\multicolumn{6}{c}{ Tabel 21. Persentase Bobot Kering Siung Tunggal Per Petak } & \multirow{2}{*}{ Rerata } \\
\cline { 2 - 4 } Komposisi Biochar & \multicolumn{3}{c}{ Jenis Teh Kompos } \\
\cline { 2 - 4 } & Tanpa & Murni & Teh+Biochar & \\
\hline Murni & 0,69 & 0,81 & 0,65 & $0,71 \mathrm{a}$ \\
Biochar 10 \% & 0,73 & 0,56 & 0,84 & $0,71 \mathrm{a}$ \\
Biochar 20\% & 0,64 & 0,69 & 0,71 & $0,68 \mathrm{a}$ \\
\hline Rerata & $0,69 \mathrm{a}$ & $0,69 \mathrm{a}$ & $0,73 \mathrm{a}$ & $(-)$ \\
\hline Kontrol & \multicolumn{5}{c}{0,62} \\
\hline
\end{tabular}

Keterangan: Angka pada baris dan kolom yang diikuti huruf sama menunjukkan tidak berbeda pada tingkat nyata $(\alpha) 5 \%$ menurut uji DMRT. (-) tidak terjadi interaksi antar faktor.

\begin{tabular}{ccccc} 
Tabel 22. Indeks Panen & \multicolumn{3}{c}{ Jenis Teh Kompos } & \multirow{2}{*}{ Rerata } \\
\cline { 2 - 4 } Residu Kompos & Tanpa & Murni & Teh+Biochar & \\
Biochar & 79,72 & 79,84 & 78,14 & $79,23 \mathrm{a}$ \\
Murni & 78,51 & 80,23 & 80,52 & $79,75 \mathrm{a}$ \\
Biochar 10 \% & 80,79 & 81,38 & 76,72 & $79,63 \mathrm{a}$ \\
Biochar 20\% & $79,67 \mathrm{a}$ & $80,48 \mathrm{a}$ & $78,46 \mathrm{a}$ & $(-)$ \\
\hline Rerata & \multicolumn{5}{c}{} \\
\hline Kontrol & 81,11 & \\
\hline
\end{tabular}

Keterangan: Angka pada baris dan kolom yang diikuti huruf sama menunjukkan tidak berbeda pada tingkat nyata ( $\alpha$ ) $5 \%$ menurut uji DMRT. (-) tidak terjadi interaksi antar faktor.

\subsection{Pembahasan}

Pengamatan lingkungan 75 HST menunjukkan bahwa petak yang diberi perlakuan residu kompos biochar $20 \%$ menghasilkan suhu tanah paling rendah $\left(29,37{ }^{\circ} \mathrm{C}\right)$, sedangkan petak yang diberi perlakuan aplikasi teh kompos murni menghasilkan suhu tanah terendah $\left(29,69{ }^{\circ} \mathrm{C}\right)$. Sedangkan petak yang diberi kombinasi perlakuan residu kompos murni dan aplikasi teh kompos murni menghasilkan nilai lengas tanah tertinggi $(22,30 \%)$ berat volume tanah terendah $\left(1,47 \mathrm{~g} / \mathrm{cm}^{3}\right), \mathrm{pH}$ tanah tertinggi $(6,38)$. sedangkan pada pengamatan DHL tanah tertinggi dihasilkan oleh kombinasi perlakuan residu kompos biochar $10 \%$ dan perlakuan tanpa aplikasi teh kompos $(350,89)$. Penelitian Steiner et al. , (2007) membuktikan bahwa biochar sebagai bahan pembenah tanah memiliki sifat rekalsitran, lebih tahan terhadap oksidasi dan lebih stabil dalam tanah sehingga memiliki pengaruh jangka panjang terhadap perbaikan kualitas kesuburan tanah (C-organik tanah dan KTK). Rosmarkam dan Yuwono, (2003) menambahkan bahwa residu bahan organik memberikan pengaruh yang baik dalam peningkatan kesuburan tanah baik sifat fisik, kimia maupun biologi tanah. Menurut Hairiah (2000), tingginya bahan organik dapat mempertahankan kualitas fisik tanah sehingga membantu perkembangan akar tanaman dan kelancaran siklus air tanah antara lain melalui pembentukkan pori tanah dan kemantapan agregat tanah.

Lingkungan yang optimal mampu meningkatkan pertumbuhan tanaman. Waluapun tidak terjadi interaksi antara kombinasi perlakuan, namun kombinasi perlakuan residu kompos biochar $20 \%$ dan aplikasi teh kompos + biochar menghasilkan jumlah daun tanaman terbanyak (10,07 helai), nilai luas daun tertinggi $(7,87)$, bobot kering berangkasan terberat $(29,87 \mathrm{~g})$. Interkasi antara kombinasi perlakuan terjadi pada pengamatan bobot kering akar tanaman. Nilai bobot kering akar terendah dihasilkan oleh kombinasi perlakuan residu kompos biochar $20 \%$ dan aplikasi teh kompos murni yaitu $(3,30 \mathrm{~g})$. Aging biochar meningkatnya retensi hara dan perubahan dinamika mikroba tanah sehingga keuntungan jangka panjangnya bagi ketersediaan hara berhubungan dengan stabilisasi karbon organik yang lebih tinggi seiring dengan pembebasan hara yang lebih lambat dibanding bahan organik yang biasa digunakan (Gani, 2009). Sutanto (2002a dan 2002b) menyatakan residu dari pupuk organik dapat menjadi cadangan hara sehingga dapat dimanfaatkan untuk penanaman periode selanjutnya dan pupuk organik mempunyai efek residu di mana haranya berangsur secara bebas dan tersedia bagi tanaman.

Sedangkan hasil penelitian Berek et al. ,(2017) membuktikan bahwa pertumbuhan dan hasil selada darat yang diekspresikan dalam jumlah daun, panjang akar, berat segar total per tanaman, berat segar akar per tanaman, berat segar trubus per tanaman dan berat segar total petak, meningkat dengan aplikasi biochar dikombinasikan dengan teh kompos. Pertumbuhan tanaman yang baik mampu meningkatkan hasil dan produksi tanaman, penelitian menunjukkan bahwa kombinasi perlakuan residu kompos biochar $20 \%$ dan aplikasi teh kompos murni berpengaruh secara positif menurut uji DMRT taraf $5 \%$ dalam meningkatkan jumlah umbi per petak tertinggi (146,33), menghasilkan persentase pembentukkan umbi siung tunggal tertinggi $(74,10 \%)$. Walaupun tidak terjadi interaksi antara kombinasi perlakuan, namun kombinasi perlakuan residu kompos biochar $10 \%$ dan perlakuan aplikasi teh kompos + biocharmenghasilkan jumlah umbi siung tunggal per petak terbanyak $(108,00)$, jumlah umbi siung majemuk per petak terendah $(37,33)$, persentase bobot kering umbi siung tunggal per petak tertinggi $(62,83 \%)$. Sedangkan petak yang diberi kombinasi perlakuan residu kompos murni dan Aplikasi teh kompos murni menghasilkan nilai bobot panen umbi siung tunggal per petak tertinggi $(79,60 \mathrm{~g})$, bobot kering umbi siung tunggal per petak terberat $(70,07$ g), jumlah umbi per petak terbanyak $(146,33)$, bobot kering umbi siung tunggal per tanaman $(1,40 \mathrm{~g})$.

Tanah yang ditambahkan biochar akan dapat memperbaiki agregat tanah sehingga butiran-butiran tanah akan saling terikat dengan demikian kandungan air, udara dan bahan organik (C-Organik) di dalamnya akan mudah tersedia 
bagi tanaman, sehingga kebutuhan tanaman akan nutrisi dapat terpenuhi, (Gani, 2009). Selain itu Wawan (2015) menyatakan bahwa kompos selain mampu meningkatkan kesuburan tanah juga menyediakan hara yang penting untuk tanaman. Penelitian Bria, (2016) membuktikan bahwa jenis dan konsentrasi teh kompos berpengaruh terhadap pertumbuhan dan hasil bayam merah. Walaupun tidak terjadi interkasi antara kombinasi perlakuan namun petak yang diberi kombinasi perlakuan residu kompos biochar $10 \%$ dan aplikasi teh kompos murni menghasilkan bobot panen umbi siung majemuk terberat $(75,93 \mathrm{~g})$, bobot kering umbi siung majemuk per petak terberat $(69,43 \mathrm{~g})$, bobot kering umbi per petak terberat $(109,23 \mathrm{~g})$, bobot kering umbi siung majemuk per tanaman terberat $(2,78 \mathrm{~g})$. Fatimah (2008) menyatakan bahwa pupuk organik yaitu bahan organik yang mempunyai efek residu dimana haranya berangsur bebas dan tersedia bagi tanaman, efek residu dari pupuk organik dapat menjadi cadangan hara sehingga dapat dimanfaatkan untuk periode penanaman berikutnya. Selain itu Tas'au, (2018) mengemukakan bahwa pemberian residu biochar 5 t/ha hasilnya naik $38,7 \%$, pada petak pengaruh utama pemberian residu biochar 10 t/ha hasilnya naik hanya $9,4 \%$, dibanding musim tanam sebelumnya. Penelitian Fretis, (2018) pada musim tanam pertama di lahan yang sama membuktikan bahwa kombinasi perlakuan komposisi kompos + biochar $10 \%$ dan teh kompos biochar memberikan hasil yang tertinggi pada bobot kering siung tunggal per umbi $(0,70 \mathrm{~g} / \mathrm{umbi})$ dan indeks panen $(76,69 \mathrm{~g})$.

\section{Simpulan}

Hasil penelitian menunjukkan bahwa terjadi interaksi antara kombinasi perlakuan residu kompos biochar $10 \%$ dan perlakuan aplikasi teh kompos murni terhadap kadar lengas tanah 45 HST, dan jumlah umbi per petak. Walaupun tidak terjadi interaksi antar perlakuan residu kompos murni dengan jenis teh kompos murni menghasilokan bobot umbi siung tunggal per petak terberat $0,93 \mathrm{t} / \mathrm{ha}$. Pengaruh utama perlakuan residu kompos biochar $10 \%$ lebih meningkatkan hasil bobot umbi total, bobot umbi siung tunggal, dan bobot umbi siung majemuk walaupun tidak berbeda nyata. Pengaruh utama perlakuan aplikasi teh kompos biochar meningkatkan hasil bobot umbi total, bobot umbi siung tunggal, sedangkan bobot umbi majemuk hasilnya lebih tinggi apabila menerapkan teh kompos murni.

\section{Pustaka}

Berek A. K., Ceunfin S., Taolin R.I.C.O., I., Neonbeni, Y., E., Seran M. J., 2017. Efek Biochardan Teh Kompos Terhadap Pertumbuhan dan Hasil Selada Darat (Lactuca sativa L.) di Tanah Vertisol Semiarid. Pusat Studi Lahan Kering, Universitas Timor, Kefamenanu, TTU - NTT, Indonesia.

BPS Kab. TTU, 2011. Timor Tengah Utara dalam Angka. Badan Pusat Statistik Kabupaten Timor Tengah Utara (TTU), Kefamenanu.

BPS RI, 2014. Statistik Indonesia. Badan Pusat Statistik Republik Indonesia, Jakarta.

Bria, D. 2016. Pengaruh jenis dan konsentrasi teh kompos terhadap pertumbuhan dan hasil bayam merah (Alternanthera amoena,Voss). Jurnal Pertanian Konservasi Lahan Kering, Fakultas Pertanian, Universitas Timor, Kefamenanu, TTU-NTT, Indonesia

Direktorat Gizi Departemen Kesehatan R.I, 1997. Daftar Komposisi Bahan Makanan. Bhratara Karya Aksara: Jakarta.

Fatimah. 2008. Pengaruh Pemberian Pupuk Organik Terhadap Pertumbuhan dan Produksi Tanaman Caisim (Brassica campestrisvar Chinensis). Skripsi Fakultas Pertanian. Universitas Riau. Pekanbaru. (Tidak dipublikasikan).

Fretis, M. Y. M. 2018. Pengaruh Komposisi Biochar Dalam Kompos Sebagai Bahan Pupuk Dasar Dan Sebagai Bahan Dasar Aplikasi Teh Kompos Terhadap Pertumbuhan Dan Hasil Bawang Putih (Allium Sativum L) Siung Tunggal. Skripsi Agroteknologi. Fakultas Pertanian Universitas Timor. TTU. NTT

Gani, A. 2009. Potensi Arang Hayati Biochar Sebagai Komponen Teknologi Perbaikan Produktivitas Lahan Pertanian. Iptek Tanaman Pangan Vol. 4 No. 1: 33-48

Gomez, K.A., Gomez, A. A. 2010. Prosedur Statistik Untuk Penelitian Pertanian. Edisi ke 2. UI Press: Jakarta.

Hairiah, K., S. R. Utami, D. Suprayogo, D. Widianto,S. M. Sitompul, Sunaryo, B. B. Lusiana, R. Mulia, M. Van Nordwijk, dan G. Cadisch. 2000 Agroforestri pada Tanah Masam di Daerah Tropika Basah: Pengelolaan Interaksi Antara Pohon Tanaman Semusim. International Centre for Research in Agroforestry (ICRAF). Bogor.

Jamilah,Yohanes, Widodo, I. 2008. Efek Residu Kompos C. odorata Dan Guano upaya Menghemat pupuk Buatan Untuk Tanaman Bawang pada Tanah Marginal. Fakultas. Pertanian Universitas Tamansiswa

Mulyono. E (2014). Membuat MOL dan Kompos dari sampah rumah tangga. Agromedia pustaka. Jakarta

Prasonto, D. Riayanti, E. Kartika, M. 2017. Jurnal Uji Antioksidan Ekstrak bawang Putih (Allium sativum $\mathrm{L}$ )

Retno, A., dan S. Darmanti, 2009. Pengaruh Dosis Kompos dengan Stimulator Trichoderma terhadap Pertumbuhan dan Produksi Tanaman Jagung (Zea mays L.) Varietas Pionerr-11 pada Lahan Kering. Jurnal Bioma, Vol. 11 No. 2 : Hal 69-75.
Rosmarkam A., Yuwono N. W. 2003 Ilmu Kesuburan Tanah. Gajah Mada University. Press, Yogyakarta.

Samira, D. 2012. Pengaruh Pemupukan NPK dan Residu Biochar Terhadap Sifat Kimia Tanah, Kandungan Hara, dan Hasil Tanaman Padi Sawah (Oryza sativa L.) Musim Tanam II. Thesis. Universitas Syiah Kuala. Banda Aceh.

Steiner, Christoph, Teixeira, Wenceslau, Lehmann, Johannes, Nehls, Thomas, de Macdo, Jeferson, Blum, Winfried, and Zech, Wolfgang. 2007. Long term effects of manure, charcoal and mineral fertilization on crop production and fertility on a highly weatehred Central Amazonian upland soil. Plant and Soil 291: 275-290. Springer Netehrlands. ing. Jurnal Bioma, Vol. 11 No. 2 : Hal 69-75

Sutanto, R., Penerapan Pertanian Organik. Permasyarakatan dan pengebangannya. Penerbit Kanisius. Yogyakarta.

Tas'au, Ferdynandus. 2018. Kajian Residu Pupuk Guano Dan Aging Biochar TerhadapPertumbuhan Dan Hasil Kacang Merah Di Dataran MenengahPada Musim Tanam Kedua. 